\title{
Bonamia parasites: a rapidly changing perspective on a genus of important mollusc pathogens
}

\author{
Marc Y. Engelsma ${ }^{1, *}$, Sarah C. Culloty ${ }^{2}$, Sharon A. Lynch ${ }^{2}$, Isabelle Arzul ${ }^{3}$, \\ Ryan B. Carnegie ${ }^{4}$ \\ ${ }^{1}$ Central Veterinary Institute of Wageningen UR (CVI), PO Box 65, 8200 AB, Lelystad, The Netherlands \\ ${ }^{2}$ Aquaculture \& Fisheries Development Centre, School of Biological, Earth \& Environmental Sciences, \\ University College Cork, Distillery Fields, North Mall, Cork, Ireland \\ ${ }^{3}$ Ifremer, Laboratory of Genetics and Pathology, Av de Mus de Loup-17390, La Tremblade, France \\ ${ }^{4}$ Virginia Institute of Marine Science, College of William \& Mary, PO Box 1346, Gloucester Point, Virginia 23062, USA
}

\begin{abstract}
Organisms of the genus Bonamia are intracellular protistan parasites of oysters. To date, 4 species have been described (B. ostreae, B. exitiosa, B. perspora and B. roughleyi), although the status of $B$. roughleyi is controversial. Introduction especially of $B$. ostreae and $B$. exitiosa to naïve host populations has been shown to cause mass mortalities in the past and has had a dramatic impact on oyster production. Both $B$. ostreae and B. exitiosa are pathogens notifiable to the World Organisation for Animal Health (OIE) and the European Union. Effective management of the disease caused by these pathogens is complicated by the extensive nature of the oyster production process and limited options for disease control of the cultured stocks in open water. This review focuses on the recent advances in research on genetic relationships between Bonamia isolates, geographical distribution, susceptible host species, diagnostics, epizootiology, host-parasite interactions, and disease resistance and control of this globally important genus of oyster pathogens.
\end{abstract}

KEY WORDS: Bonamia ostreae $\cdot$ Bonamia exitiosa $\cdot$ Oyster disease $\cdot$ Phylogenetics $\cdot$ Geographical spread $\cdot$ Diagnostics $\cdot$ Epizootiology $\cdot$ Host-parasite interaction $\cdot$ Bonamiosis

Resale or republication not permitted without written consent of the publisher

\section{INTRODUCTION}

Since their first detection and description, intracellular protistan parasites of the genus Bonamia have been recognized as serious pathogens of oysters, severely impairing the health of oyster populations and the production of these economically important molluscs. The appearance of $B$. ostreae in the $1970 \mathrm{~s}$ in Europe caused mass mortality in its host Ostrea edulis and hastened the decline of this species (Grizel 1985, Montes 1990, Hudson \& Hill 1991, McArdle et al. 1991, Van Banning 1991). This was a dramatic impact that may have reflected the encounter between an introduced pathogen (Elston et al. 1986) and a host with no natural resistance to it. The effects of $B$. exitiosa infection of $O$. chilensis in New Zealand have been similarly severe, reducing the population to $9 \%$ of the pre-disease level, although this hostparasite relationship may be long-standing (Doonan et al. 1994, Hine \& Jones 1994). The impact of $B$. exitiosa on European oyster populations since its discovery in Europe is less clear. The extensive nature of the oyster production process and limited options for disease control in cultured stocks in open water surrounded by wild oyster populations hampers effective management of disease outbreaks. Both $B$. ostreae and $B$. exitiosa are pathogens listed by and notifiable to the World Organisation for Animal Health (OIE) and the European Union (EU). With the advances in research on Bonamia species over the years, knowledge on their global spread has been extended, as additional species have been discovered and assigned 
to the genus Bonamia (Carnegie et al. 2006). Hosts are now known to include not only ostreid oysters but also Crassostrea species. Recently, mechanisms of interaction between Bonamia spp. and their hosts, including mechanisms involved in the resistance to the disease, have been investigated in more depth at cellular and molecular levels (Morga et al. 2009, 2011, 2012). Furthermore, it seems that in some cases, after their introduction, the parasites are only present at a low prevalence and with presumably limited effects on the population (Culloty \& Mulcahy 2007). In other populations exposed to the parasites over a long period of time, there are indications that a certain level of resistance is acquired (Culloty et al. 2004).

In this review, we focus on the advances in research on Bonamia over the last decade in phylogenetics, geographical distribution, susceptible host species, diagnostics, epizootiology, host-parasite interactions, and disease resistance and control.

\section{PHYLOGENETICS AND TAXONOMY}

The genus Bonamia represents a derived clade within the phylum Haplosporidia whose members have generally adopted (1) life cycles based on direct oyster to oyster transmission of uninucleate amoeboid cell forms, and (2) intracellular infection of oyster haemocytes by these cell forms (Carnegie et al. 2000, Carnegie \& Cochennec-Laureau 2004). The 4 described species are $B$. ostreae, described from Ostrea edulis in France (Pichot et al. 1980); B. exitiosa, from O. chilensis in New Zealand (Hine et al. 2001, Berthe \& Hine 2003); B. roughleyi, originally identified as Mikrocytos roughleyi, from Saccostrea glomerata in southeastern Australia (Farley et al. 1988, Cochennec-Laureau et al. 2003b); and B. perspora, from $O$. stentina (= Ostreola equestris; Shilts et al. 2007) in the southeastern USA (Carnegie et al. 2006; Fig. 1). Among these species, B. perspora is unique in retaining the basal haplosporidian characteristics of spore formation (Fig. 2) and extracellular infection. Expression of conventional haplosporidian spores by a Bonamia species, the possession of haplosporosomes by members of the genus (Pichot et al. 1980, Dinamani et al. 1987, Carnegie et al. 2006) and compelling phylogenetic evidence (Carnegie et al. 2000, 2006, Reece et al. 2004) indicate that placement of Bonamia within the Haplosporidia is correct. Small subunit ribosomal DNA (SSU rDNA)-based analyses typically support a sister relationship of Bonamia to the genus Minchinia (Carnegie \& Cochennec-Laureau 2004, Reece et al. 2004, Carnegie et al. 2006, Abollo et al. 2008; Fig. 3 and see the Supplement at www.int-res.com/articles/ suppl/d110p005_supp.pdf), although the single analysis performed to date using actin gene and amino acid sequences has been more ambiguous (LópezFlores et al. 2007).

Morphology at the light microscope level provides little perspective with regard to the inter-specific relationships among Bonamia parasites, except to indi-

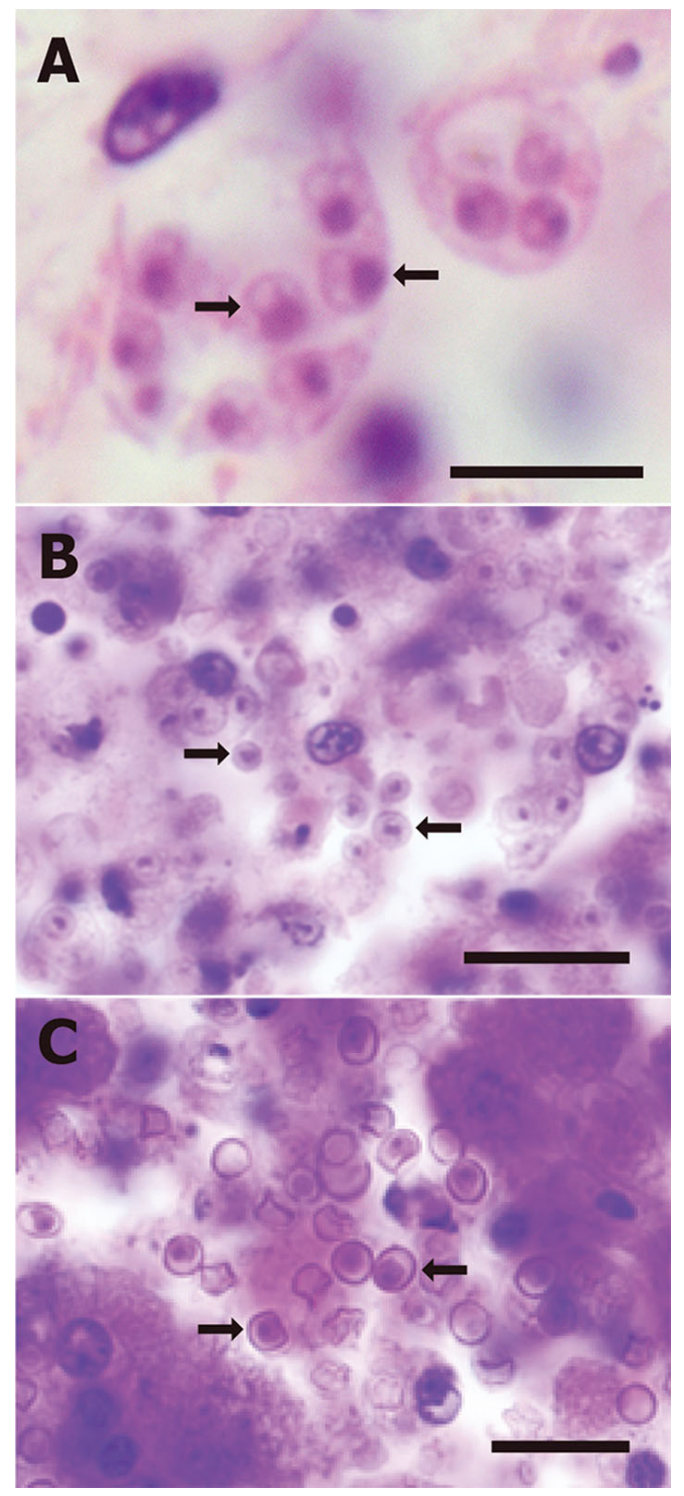

Fig. 1. Valid described species in the genus Bonamia (histopathological haematoxylin and eosin staining). (A) B. ostreae in Ostrea edulis from Maine, USA. Scale bar $=5 \mu \mathrm{m}$. (B) $B$. exitiosa in Crassostrea ariakensis from North Carolina, USA. Scale bar $=10 \mu \mathrm{m}$. (C) B. perspora in O. stentina from North Carolina, USA. Representative parasite cells in each image are indicated by arrows. Scale bar $=10 \mu \mathrm{m}$. Specimens are from the Virginia Institute of Marine Science Shellfish Pathology Laboratory collections 


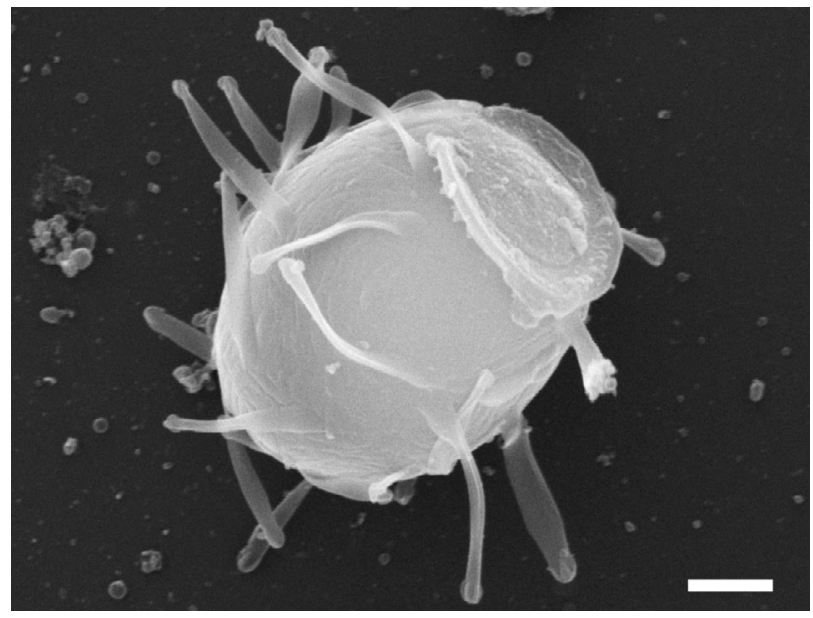

Fig. 2. Scanning electron micrograph of a Bonamia perspora spore from Ostrea stentina from North Carolina, USA. Scale bar $=600 \mathrm{~nm}$. Image is from the Virginia Institute of Marine

Science Shellfish Pathology Laboratory collections

cate that B. perspora is distinctive. Transmission electron microscopy (TEM) can sometimes be useful, suggesting, for example, that a Bonamia sp. from $O$. chilensis from Chile is more closely related to $B$. exitiosa than to B. ostreae and B. perspora (Lohrmann et al. 2009). SSU rDNA-based molecular phylogenetic analyses have provided more resolution, indicating a close relationship of $B$. roughleyi to $B$. exitiosa (e.g. Carnegie \& Cochennec-Laureau 2004, Abollo et al. 2008). Analyses using this locus have shown an affinity of numerous additional Bonamia parasites observed in recent years to a $B$. exitiosa-B. roughleyi clade, including the Bonamia spp. from $O$. chilensis in Chile (Campalans et al. 2000), Crassostrea ariakensis and $O$. stentina in the southeastern USA (Burreson et al. 2004, Carnegie et al. 2006), O. puelchana in Argentina (Kroeck \& Montes 2005), O. angasi in southeastern Australia (Corbeil et al. 2006b), O. edulis in Spain and Italy (Abollo et al. 2008, Narcisi et al. 2010, Carrasco et al. 2012) and O. stentina in Tunisia (Hill et al. $2010 b)$. While some of these parasites were explicitly identified as $B$. exitiosa upon their discovery, these identifications were inconclusive given the presence of $B$. roughleyi in the same clade (Hill et al. 2010b). Recent work with Australian samples, however, has indicated that the parasite visually observed as Mikrocytos roughleyi (Farley et al. 1988) is not a Bonamia or Mikrocytos species at all (Carnegie et al. 2014, Spiers et al. 2014, this DAO Special), and that the parasite genetically identified in $S$. glomerata from Australia (Cochennec-Laureau et al. 2003b) could be a mis-identified $B$. exitiosa. The implication of this is that the parasites from $O$. chilensis in New
Zealand, O. angasi from Australia, O. stentina from the southeastern USA and the Mediterranean, $O$. stentina and $O$. puelchana from Argentina (see Hill et al. 2014, this DAO Special, M. A. Kroeck et al. unpubl.), and the non- $B$. ostreae parasites from $O$. edulis in Mediterranean Spain (Carrasco et al. 2012) should all be considered $B$. exitiosa based on the current state of the genetics.

While $B$. roughleyi appears not to be a Bonamia parasite, both SSU rDNA- and higher-resolution, internal transcribed spacer (ITS) ribosomal regionbased phylogenetic analyses point to a Hawaiian par-

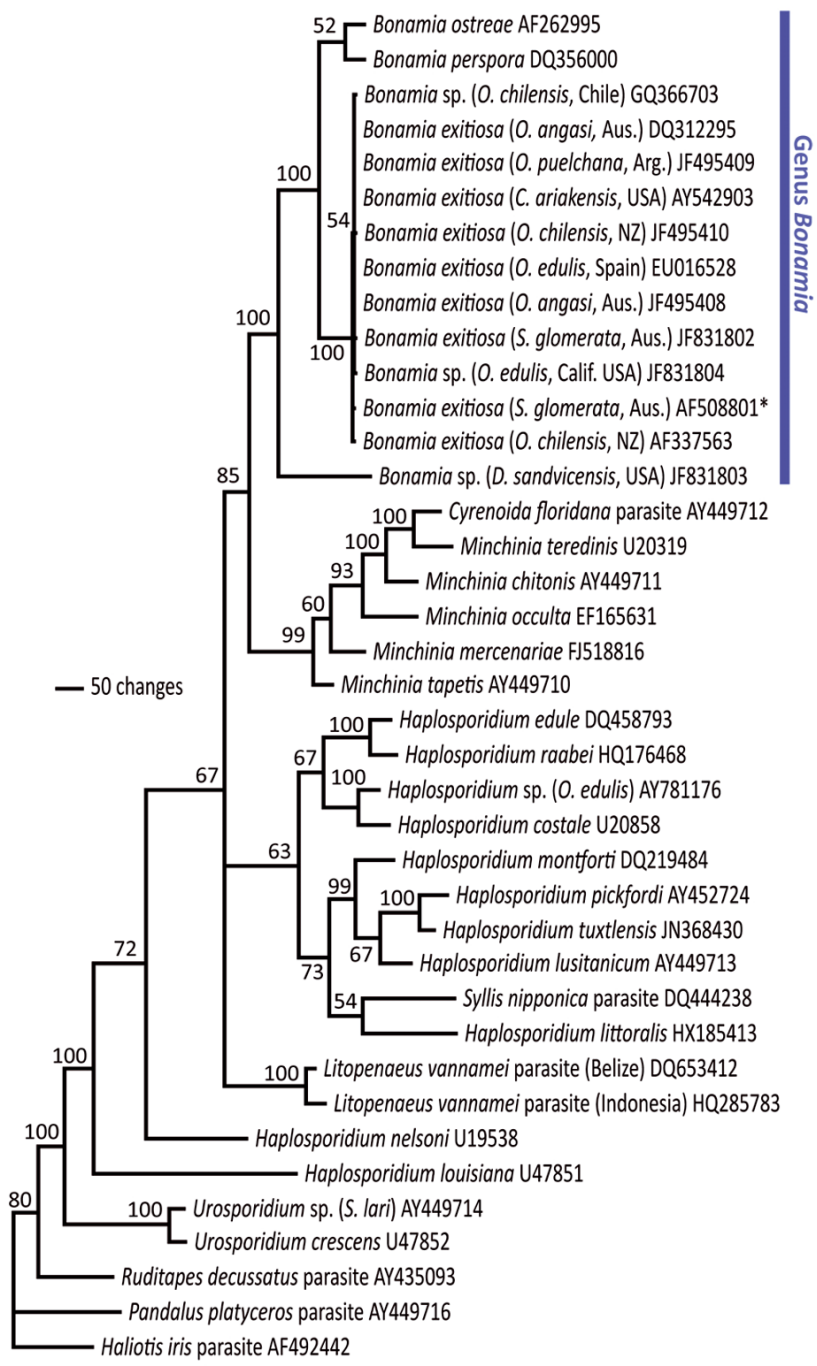

Fig. 3. Parsimony bootstrap analysis of haplosporidian small subunit ribosomal DNA (SSU rDNA) sequences: $50 \%$ majority rule consensus tree, with numbers at nodes representing percentages of 1000 bootstrap replicates. Tree length = 4299 , retention index $=0.6071$, consistency index $=0.5015$. Asterisk indicates the sequence originally identified as Bonamia roughleyi by Cochennec-Laureau et al. (2003b). GenBank accession numbers of the SSU rDNA sequences are indicated after the species names 
asite of Dendostrea sandvicensis as being a distinct Bonamia species (Hill et al. 2014). Interestingly, although its histological presentation suggests a typical 'microcell haplosporidian' Bonamia parasite (Fig. 4A), the SSU rDNA-based analyses place the Hawaiian Bonamia sp. at the base of the Bonamia clade (Fig. 3). The placement on an interior branch of $B$. perspora, with its retention of the presumably ancestral characteristics of spore formation and extracellular infection, suggests either that the other Bonamia lineages giving rise to B. ostreae, B. exitiosa and the Hawaiian Bonamia

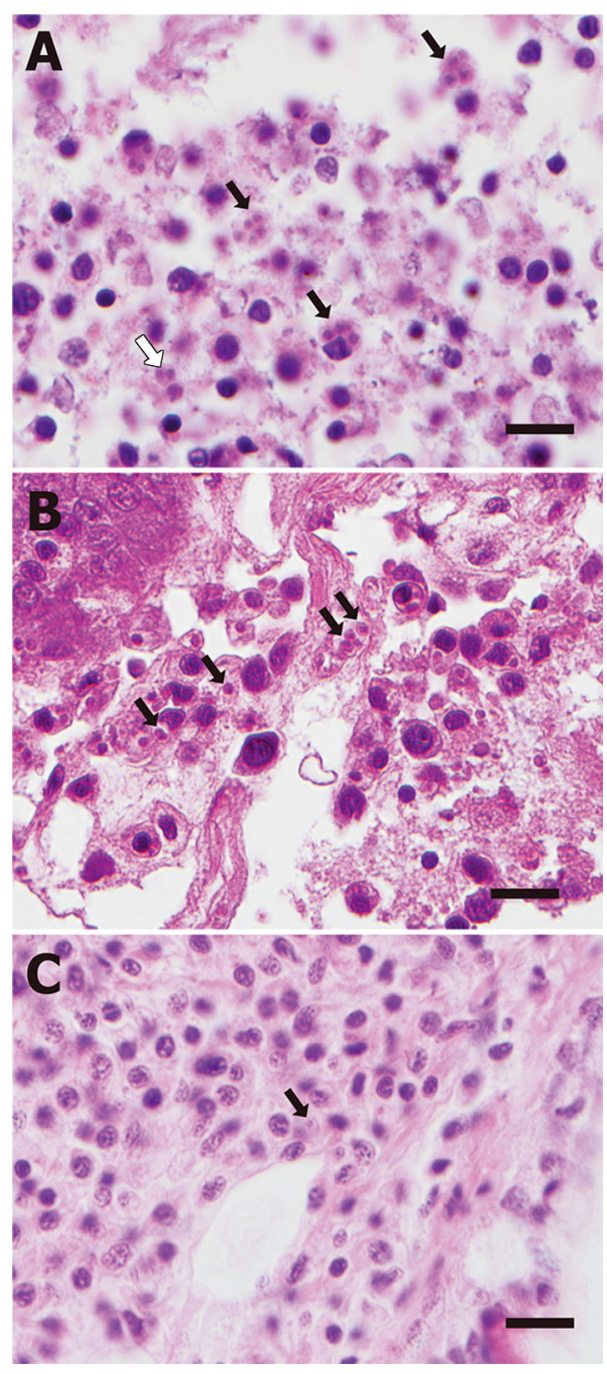

Fig. 4. Undescribed Bonamia parasites (histopathological haematoxylin and eosin staining). (A) Bonamia sp. from Dendostrea sandvicensis in Hawaii, with numerous intrahaemocytic and free cells (arrows) including a binucleate stage at lower left (white arrow). (B) Bonamia sp. from Ostrea chilensis in Chile, with numerous parasite cells present (arrows). (C) Bonamia sp. from O. edulis in California, USA, with a single cell displayed (arrow). All scale bars $=10 \mu \mathrm{m}$. Specimens are from the Virginia Institute of Marine Science Shellfish Pathology Laboratory collections sp. adopted direct transmission by uninucleate amoeboid forms and intracellular infection multiple times over the evolutionary history of the genus, or, conversely, that the SSU rDNA gene trees do not reflect the species tree for Bonamia (Hill et al. 2014). Future analyses using additional genetic loci may shed further light on this. It should be noted that $B$. perspora has appeared in 1 analysis to be a sister to $B$. ostreae (Abollo et al. 2008); however, this relationship has not been strongly supported elsewhere (Hill et al. 2014).

What of the Chilean Bonamia sp. (Fig. 4B)? While SSU rDNA-based phylogenetic analyses suggest an affinity to $B$. exitiosa (Abollo et al. 2008, Hill et al. 2010b), higher-resolution ITS region-based analyses reveal a distinct lineage reciprocally monophyletic both with $B$. exitiosa and with another distinct lineage from O. edulis from California, USA (Hill et al. 2014; our Fig. 4C). These should not be considered B. exitiosa, based on their novel ITS sequences, and may represent fifth and sixth novel Bonamia species that, like the Hawaiian Bonamia sp., also await description.

In summary, the genus Bonamia as we currently appreciate it appears to comprise a possible basal parasite from $D$. sandvicensis in Hawaii, and then 3 lineages among which sister relationships cannot clearly be resolved. One is represented by $B$. perspora, and another by B. ostreae. B. exitiosa occupies the third lineage, along with the undescribed parasites from $O$. chilensis in Chile and O. edulis in California (see Hill et al. 2014).

\section{GEOGRAPHICAL DISTRIBUTION}

Until a decade ago, the geographical distribution of Bonamia species appeared to be straightforward. $B$. ostreae was the Bonamia species present in the Northern Hemisphere, infecting the European flat oyster Ostrea edulis in Europe and in Maine and California in the USA. The introduction and spread of $B$. ostreae within Europe has foremost been linked to transfers of shellfish (Peeler et al. 2010), either directly or, for example, via other anthropogenic routes such as hull fouling (Howard 1994).

In the Southern Hemisphere, the Bonamia species infecting the Chilean oyster $O$. chilensis in New Zealand was designated B. exitiosa (Hine et al. 2001, Berthe \& Hine 2003). Flat oyster species from Australia, Chile and Argentina were infected with Bonamia species similar or identical to $B$. exitiosa (Corbeil et al. 2006b, Lohrmann et al. 2009, Hill et al. 2014). In recent years, however, the known geographical distribution of $B$. exitiosa and related parasites has ex- 
panded, possibly as a result of further spread of the parasite, increased scrutiny of oyster populations that were previously ignored, and wider application of molecular methods including DNA sequencing. A Bonamia species similar to $B$. exitiosa was first observed in the Northern Hemisphere in Crassostrea ariakensis in North Carolina, USA (Burreson et al. 2004). It was subsequently found in Florida (Dungan et al. 2012), and the novel species B. perspora was detected in $O$. stentina in the same region (Carnegie et al. 2006). In 2008, a B. exitiosa-like parasite was reported from $O$. edulis in Galicia, Spain (Abollo et al. 2008), and subsequent years brought reports of $B$. exitiosa-like parasites from the Mediterranean coastlines of Tunisia (Hill et al. 2010b) and Spain (Carrasco et al. 2012), the Adriatic Sea shore of Italy (Narcisi et al. 2010, WAHID-Interface 2010), and a single location in the UK (WAHID-Interface 2011). As we now recognize that most of the $B$. exitiosa-like parasites are indeed $B$. exitiosa, we must view $B$. exitiosa as having a wide host (see next section) and geographic range. Its distributions in Asia and Africa and along the tropical and sub-tropical coasts of all the continents are important remaining questions. ITS region characterization of the parasite from the Atlantic coast of Europe remains to be performed for definitive assignment to $B$. exitiosa, but it is widely assumed to be $B$. exitiosa (e.g.
Abollo et al. 2008). ITS sequencing of the Bonamia sp. from the Mediterranean coast of Spain confirmed that parasite to be B. exitiosa (N. Carrasco \& R. B. Carnegie unpubl. data).

Hill et al. (2010a) summarised the known geographical distributions of $B$. ostreae and B. exitiosa in a recent literature study for the European Food Safety Authority (EFSA). Fig. 5 represents an update from this study, with the current global distribution of all known Bonamia species (more precise location details are given in Table S1 in the Supplement).

\section{SUSCEPTIBLE HOST SPECIES}

Primarily oysters of the genus Ostrea have been described as host species of the different Bonamia parasites. However, Bonamia species have also been observed in Crassostrea species including $C$. ariakensis and $C$. angulata and in the lophine oyster Dendostrea sandvicensis. Based on our present knowledge, therefore, Bonamia species seem to have an affinity more generally for members of the family Ostreidae. However, which hosts are susceptible to which parasite species is not perfectly clear.

A susceptible host species can be defined as a species that can support replication of an agent or an

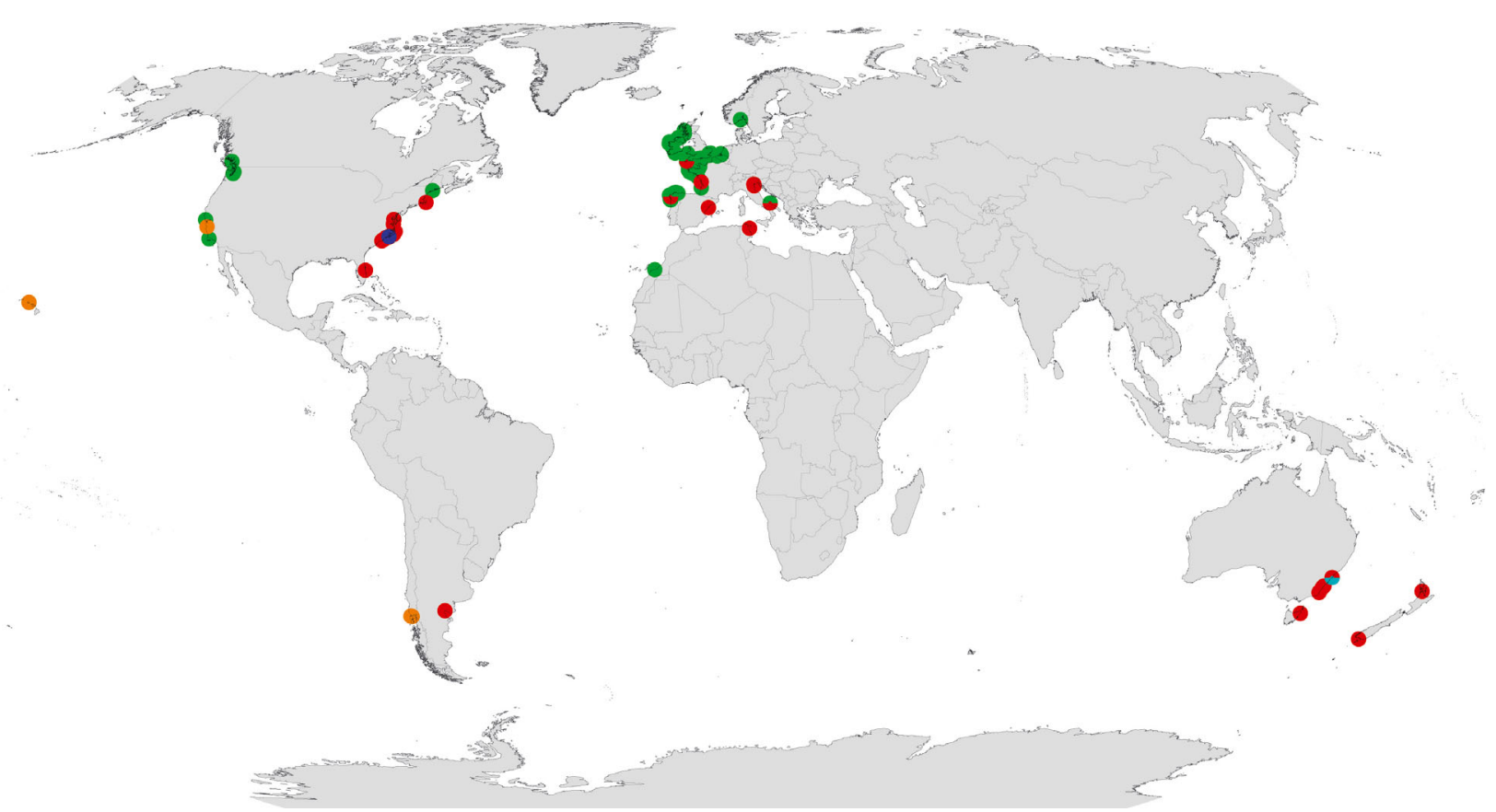

Fig. 5. Geographical distribution of Bonamia species based on published literature and disease reports of the OIE World Animal Health Information Database (see Table S1 in the Supplement at www.int-res.com/articles/suppl/d110p005_supp.pdf): B. ostreae (green), B. exitiosa and species of the B. exitiosa clade (red), Bonamia sp. from Ostrea chilensis in Chile, O. lurida in California and O. sandvicensis in Hawaii (orange), B. perspora (dark blue) and the microcell in Saccostrea glomerata (light blue) 
infection, which may lead to the development of disease (Stentiford et al. 2009). EFSA expanded this definition to identify 4 criteria for use in identifying a susceptible host, as distinct from a mechanical carrier: (A) evidence of replication or growth of the organism; (B) presence of a viable organism; (C) presence of specific clinicopathological changes; and (D) specific location of the pathogen within the host (EFSA 2008). For the Bonamia species, characteristics and techniques supporting the different criteria are, for example, binucleate plasmodia in TEM or impression smears as evidence of replication (satisfying Criterion A); purification and cell viability tests and cohabitation with passage to a specific pathogen-free susceptible host as presence of a viable organism (B); focal to disseminated haemocytic infiltration of the connective tissues and intracellular parasite present in haemocytes as indication of clinicopathological changes (C); and in the case of Bonamia species, the location of the pathogen within the host (D) is often a systemic infection.

Tables $1 \& 2$ show the results of application of these criteria to species described in the literature as hosts for $B$. ostreae and $B$. exitiosa, respectively. The data represent an updated version of the tables in the EFSA report on aquatic animal species susceptible to diseases listed in Directive 2006/88/EC (EFSA 2008). Based on the results, hosts can be assigned to 2 main groups: Group I includes host species for which the quality of the data provides clear support for susceptibility, and Group II includes host species for which incomplete or unclear data prevent a clear conclusion. A primary limitation prevents inclusion of some of the potential host species for Bonamia into the first group: the Bonamia species involved in a case has frequently not been typed to the species level. This is especially the case in early publications but also in some of the more recent work. For example, a Bonamia sp. was detected in early field trials with O. chilensis (Grizel et al. 1983), O. angasi (Bougrier et al. 1986) and $O$. puelchana (Pascual et al. 1991) in French waters. As the oysters were reared in $B$. ostreae-enzootic waters, this parasite may well have been observed. However, in the light of our present knowledge of the occurrence of $B$. exitiosa in Europe and other cryptic lineages elsewhere (Hill et al. 2014), genetic identification of the parasite is essential.

As a result for B. ostreae, current scientific data support susceptibility of $O$. edulis and $C$. ariakensis to infection with this species (Table 1). Some scientific data suggest susceptibility of $O$. angasi, O. puelchana and $O$. chilensis; however, uncertainty on parasite identification and taxonomic affiliation limits conclu- sions concerning susceptibility of these species to $B$. ostreae. In addition, available data do not support susceptibility of $O$. lurida (= O. conchaphila, Polson et al. 2009). Information on C. angulata was considered insufficient to scientifically assess susceptibility. A recent publication by Lynch et al. (2010) considers the role of $C$. gigas as a potential carrier of $B$. ostreae and $B$. exitiosa. Under field and laboratory conditions, microcells were incidentally observed in connective tissue of $C$. gigas kept in a B. ostreae-enzootic area or co-habitated with infected $O$. edulis. This might represent an actual infection or the uptake of the parasite released from dying $O$. edulis. Additional support of the findings would be helpful to fully assess the actual susceptibility of C. gigas to B. ostreae.

For $B$. exitiosa, the picture with respect to host specificity is resolved more clearly, though likely incompletely. Unambiguous genetic data combined with visual observations support susceptibility of $O$. chilensis, O. angasi, O. lurida, O. edulis, O. puelchana, O. stentina and $C$. ariakensis (Table 2). Based on recent observations in the eastern USA, C. virginica also seems to be a susceptible host for $B$. exitiosa (WAHID-Interface 2012). In C. gigas, B. exitiosa was only detected by PCR (Lynch et al. 2010), so actual infection of this species remains an open question. While $B$. exitiosa was unambiguously detected using molecular methods in S. glomerata from southeastern Australia, visual evidence of infection remains elusive. The parasite observed in this oyster by Farley et al. (1988) does not seem to have been a Bonamia sp. (Carnegie et al. 2014, Spiers et al. 2014), and while a Bonamia sp. was reported to have been observed using TEM by Cochennec-Laureau et al. (2003b), it is unclear whether these authors actually visualized a Bonamia sp. The potential susceptibility of $S$. glomerata, like $C$. gigas, remains uncertain.

As noted above, O. chilensis in Chile and O. edulis in California host sister Bonamia sp. lineages to $B$. exitiosa. For the species $B$. perspora, the only described host is O. stentina (= Ostreola equestris, Carnegie et al. 2006). Similarly, the Bonamia sp. from Hawaii is described with $D$. sandvicensis as the host species (Hill et al. 2014).

Oyster beds are naturally associated with a wide range of benthic and fouling organisms. Similar to non-susceptible bivalve species, these species are not considered susceptible hosts for Bonamia, but they could conceivably act as mechanical vectors in the spread of the parasite. Lynch et al. (2007) detected the presence of $B$. ostreae DNA by PCR in 8 benthic macro-invertebrates and 19 zooplankton samples. In subsequent laboratory trials, B. ostreae 


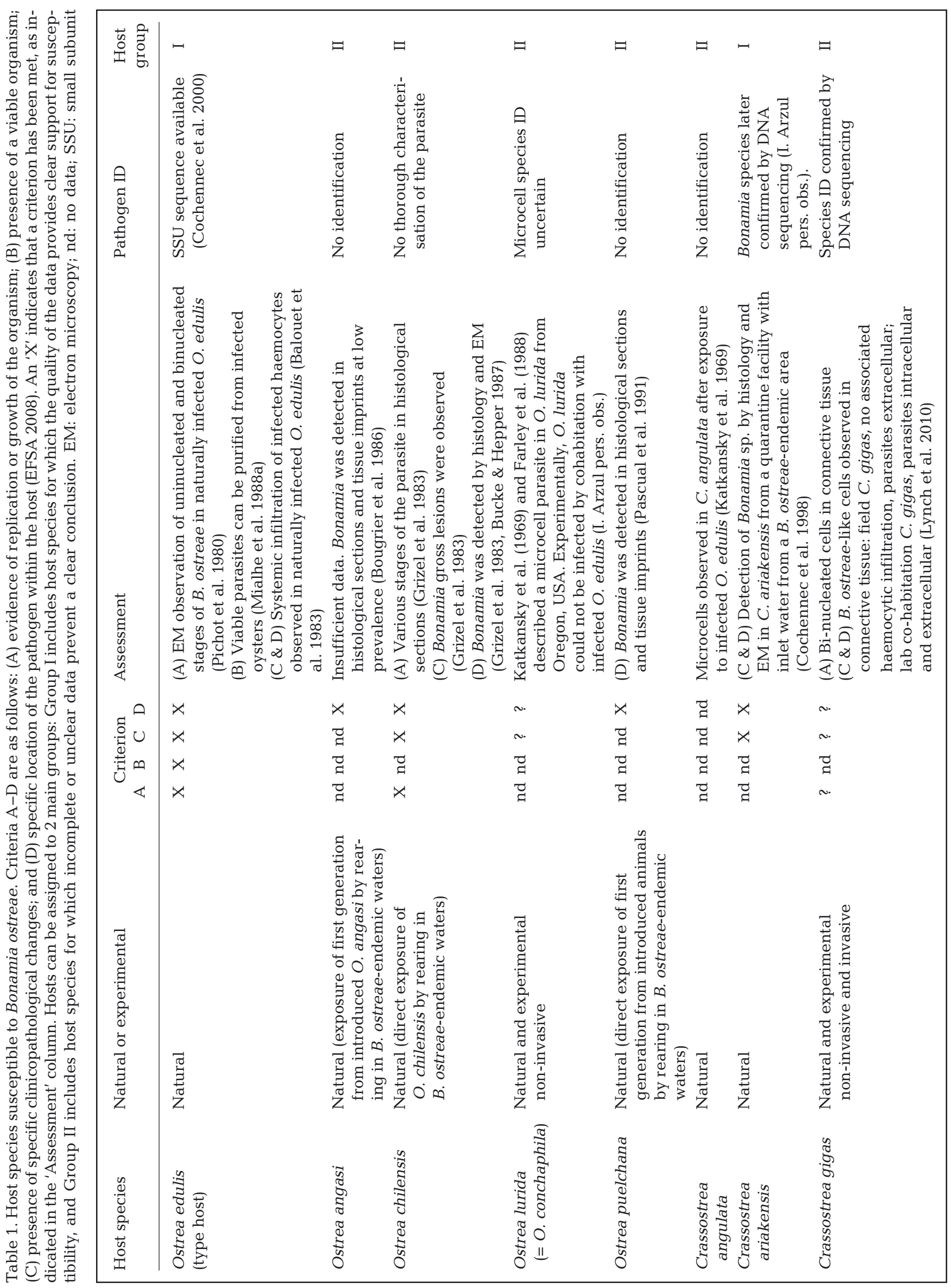




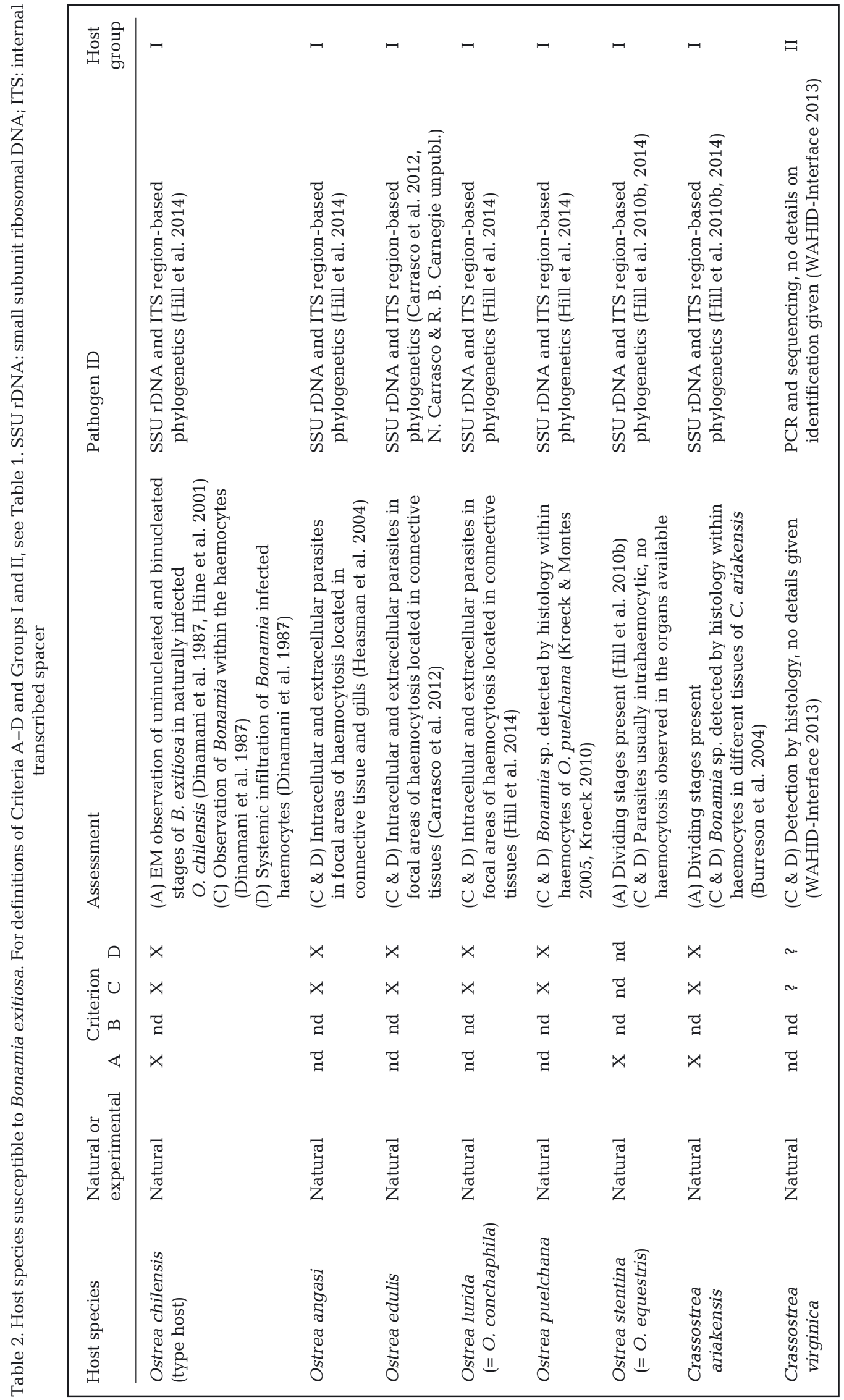


could be transmitted by co-habitation to 2 naïve oysters held with a brittle star Ophiothrix fragilis from a B. ostreae-endemic area.

\section{DIAGNOSTICS}

Since the first description of Bonamia ostreae, a range of detection techniques for Bonamia species has been developed. The first descriptions of $B$. ostreae (Pichot et al. 1980) and B. exitiosa (Dinamani et al. 1987) were based on histology and TEM. Together with cytology (stained ventricular heart imprints), histology and TEM were the main methodologies used for detection and identification of Bonamia species until the more recent development of molecular techniques. Tissue imprints and histopathology are still widely used for detection today, and are recommended methods for targeted surveillance according to the OIE manual of diagnostic tests (OIE 2012). TEM has its limitations in routine surveillance but is recommended for confirmatory diagnosis. Its primary value lies in allowing visual discrimination of Bonamia spp., which possess haplosporosomes (Pichot et al. 1980, Dinamani et al. 1987, Carnegie et al. 2006), from Mikrocytos spp., which do not (Hine et al. 2001).

Several papers have compared the detection of Bonamia by histology with detection by cytology, but the results are not conclusive. In some studies, cytology was found to be more sensitive than histology (Diggles et al. 2003, Lynch et al. 2008). In others, histology was more sensitive (Zabaleta \& Barber 1996, Balseiro et al. 2006) or the methods were comparable (da Silva \& Villalba 2004). For both assays, skilled and trained personnel are needed, and differences between the assays might reflect the background and particular capabilities of the laboratories. Results of interlaboratory comparison tests organised by the EU Reference Laboratory for Molluscan Diseases (Ifremer, La Tremblade) in 2007, 2009 and 2012 (with 20,18 and 21 participating laboratories, respectively) revealed general competency in both techniques but with more infections detected cytologically (I. Arzul unpubl. data). In general, cytology is more economical, while histology facilitates the detection of other lesions and pathogens. However, both of these methods as well as TEM lack the specificity to type the observed Bonamia to species level.

The first molecular assays for $B$. ostreae were antibody-based, but these assays were applied only occasionally (Mialhe et al. 1988b, Boulo et al. 1989, Cochennec et al. 1992, Zabaleta \& Barber 1996) and were abandoned with the development of genetic methods. After the elucidation of the first genetic sequences of $B$. ostreae in the late 1990s, a range of molecular detection methods became available. Conventional PCR assays described by Carnegie et al. (2000) and Cochennec et al. (2000) are based on sequences of the SSU rDNA of $B$. ostreae and will amplify all (Cochennec et al. 2000) or most (Carnegie et al. 2000) of the identified Bonamia spp., including $B$. exitiosa. Primer mismatches to the Hawaiian Bonamia sp. and B. perspora may limit amplification of those species using the assay of Carnegie et al. (2000). Under certain circumstances, the primers of Cochennec et al. (2000) generate a $295 \mathrm{bp}$ non-specific product of approximately the same size as the expected product of $300 \mathrm{bp}$ (Carrasco et al. 2012, M. Y. Engelsma et al. unpubl. results). TaqMan real-time PCR assays have been developed to target the same gene, and are likely to amplify a number of Bonamia lineages, including $B$. ostreae and B. exitiosa (Corbeil et al. 2006a, Marty et al. 2006). A new conventional PCR assay (319F/ 524R) was designed to amplify a $\sim 205$ bp region with the widest possible Bonamia spp. specificity, and will amplify all known lineages (Hill et al. 2010b). A SYBR Green assay developed by Robert et al. (2009) specifically targets the actin-1 gene sequence of $B$. ostreae. The different assays have been applied in a variety of studies and are recommended by the OIE (OIE 2012) for targeted surveillance and presumptive diagnostics. For confirmatory diagnostics, sequencing of the PCR products is recommended. In general, PCR and especially real-time PCR assays have the potential to be highly sensitive and specific compared to the classical detection methods of histology and cytology. Comparisons of the performance of PCR assays with histology and cytology techniques have been made in several studies. Although Lynch et al. (2008) found heart imprints to be the most sensitive technique followed by $\mathrm{PCR}$, in other studies the molecular detection methods surpassed the sensitivity of the more conventional methods (Diggles et al. 2003, Balseiro et al. 2006). In all studies, the application of a combination of techniques resulted in increased parasite detection. Use of multiple assays provides a greater likelihood that very light and local infections will be detected by one or another of the tests, thus reducing rates of false-negative results. In addition, Flannery et al. (2014, this DAO Special) found that low intensities of infection could go undetected due to the fact that the parasite could be localised within a small area of the oyster tissue which may not neces- 
sarily be screened when only very small pieces of tissue are used.

With a positive result in a PCR assay, it is necessary to bear in mind that detection of Bonamia DNA does not automatically indicate a viable parasite or an actual infection. Another drawback of most currently available PCR assays for detection of Bonamia species is the lack of specificity. Most PCR assays are generic for the genus Bonamia. A method applied to improve the specificity of the assay developed by Cochennec et al. (2000) is PCR-restriction fragment length polymorphism (PCR-RFLP) to resolve the different Bonamia species (Hine et al. 2001, CochennecLaureau et al. 2003b). In practice, it will distinguish $B$. ostreae from $B$. exitiosa when these are the only 2 possible Bonamia spp. present. One conventional PCR assay was designed for specific amplification of $B$. exitiosa, and has been in use for several years in the USA (Carnegie et al. 2008). We now know that it will also amplify members of the Bonamia sp. lineages sister to $B$. exitiosa, from $O$. chilensis in Chile and $O$. edulis in California. The PCR assays specific for $B$. ostreae and B. exitiosa, designed by Ramilo et al. (2013), represent a promising development. These species-specific primers can be used in a conventional PCR setting as well as a SYBR Green real-time PCR setting and even in combination with each other in the conventional PCR format as a dual-parasite multiplex assay. These assays will require some scrutiny before they are widely accepted, as their reverse primers bind to ITS regions that are more likely to vary intra-specifically, increasing theoretical risks of false-negative results.

The generation of false-positive results is a problem for all diagnostic assays. This becomes more critical with increasing sensitivity of the assay used. The potential for detection of false positives when using real-time PCR for detection of Bonamia has been raised by Ramilo et al. (2013). This can be an issue in Bonamia-enzootic areas, if no specific precautions are taken to prevent cross-contamination during sampling and processing of the samples (M. Y. Engelsma et al. unpubl. data). On the other hand, high sensitivity facilitates early detection of parasite, so such assays are useful tools for eradication programs. In other words, the applied sampling strategy and diagnostic method should always be fit-for-purpose (for example, demonstration of freedom or eradication, or determination of prevalence).

For localisation of the parasite in host tissues, 2 firstgeneration in situ hybridization (ISH) assays remain in use. One of these is fluorescence-based and likely to hybridize to most Bonamia spp. (Carnegie et al.

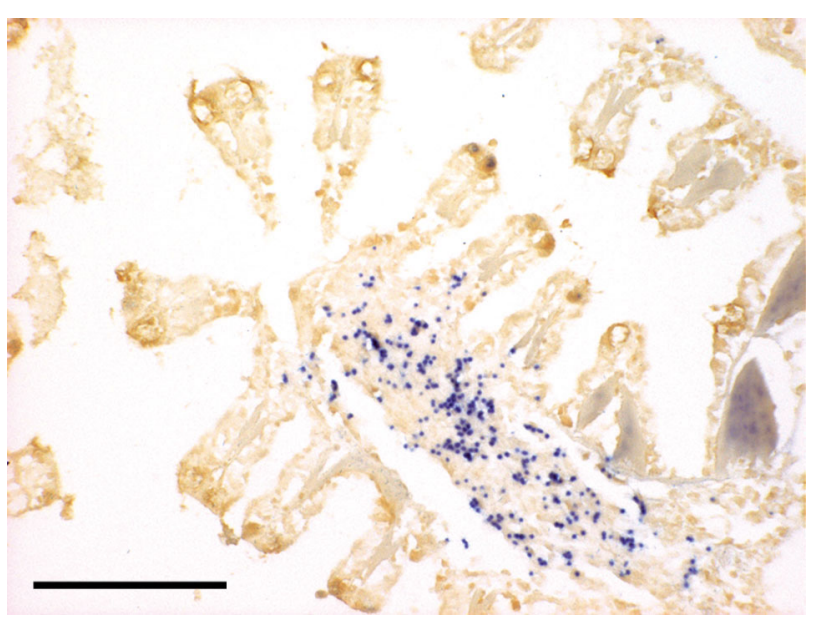

Fig. 6. In situ hybridization to Bonamia ostreae cells in the gills of Ostrea edulis. Image is from the Central Veterinary Institute collections. Scale bar $=100 \mu \mathrm{m}$

2003), and the other is chromogenic and may be more broadly specific to haplosporidians in general (Cochennec et al. 2000; Fig. 6). A newer chromogenic ISH assay detects only $B$. exitiosa and members of its sister lineages from Chilean $O$. chilensis and $O$. edulis from California (Hill et al. 2010b).

\section{EPIZOOTIOLOGY}

Bonamia ostreae can be detected in Ostrea edulis larvae (Arzul et al. 2011), and O. edulis spat can demonstrate a high prevalence of infection (Lynch et al. 2005). However, older or larger oysters frequently appear to display the heaviest levels of infection, particularly in populations that have recently been infected with the parasite and where stressors such as dredging may exacerbate infection and mortality rates (Cáceres-Martínez et al. 1995, Culloty \& Mulcahy 1996). B. exitiosa also affects larger and older oysters in a population (e.g. Dinamani et al. 1987, Kroeck \& Montes 2005), but it is not clear that this is where infection and disease effects are most severe. In general, younger oysters, especially young-of-theyear recruits, receive less attention in pathology surveys than market-sized individuals, so part of the story with regard to size-specific infection patterns may be missed. In fact, there is clear evidence that $B$. exitiosa effects are most prevalent primarily in seed oysters of some species, like Crassostrea ariakensis (Burreson et al. 2004). Infection primarily of younger animals can reflect resistance dynamics in a population subjected to highly virulent pathogens, which appears to be the situation in $C$. virginica populations 
long exposed to Haplosporidium nelsoni. H. nelsoni is an agent more of juvenile than adult oyster disease in such populations (Carnegie \& Burreson 2011). Given the similarly high pathogenicity of $B$. ostreae and $B$. exitiosa in some naïve hosts (Pichot et al. 1980, Burreson et al. 2004), we might ask whether infections by these parasites are most prevalent among younger oysters in other systems where the epizootiology among various age classes has yet to be studied. Limited evidence from the Mediterranean coast of Spain (Carrasco et al. 2012) suggests that $B$. exitiosa-O. edulis does not represent one of these systems.

Environmental factors and site-related conditions may influence disease development. Arzul et al. (2009) noted that physical characteristics such as water temperature and salinity can affect the infective capacity and spread of $B$. ostreae. Engelsma et al. (2010) observed a positive relationship between $B$. ostreae prevalence and salinity in the Netherlands, which might indicate that lower salinities are less favourable for $B$. ostreae survival. Similar results have been observed in Ireland (G. Flannery et al. unpubl. data). Arzul et al. (2009) showed that, experimentally, higher salinity $\left(\geq 35 \mathrm{~g} \mathrm{l}^{-1}\right)$ supports better $B$. ostreae survival in seawater, thus $B$. ostreae may not be able to survive in populations in low-salinity regions such as estuaries. In the well-studied $B$. exitiosa-C. ariakensis system, infection and disease pressure has been found to be strongly associated with euhalinity (Bishop et al. 2006, Audemard et al. $2008 a, b)$. This more likely reflects reduced parasite activity at lower salinities than reduced host immunocompetence at higher salinities.

$B$. ostreae infections occur throughout the year, yet many studies have documented a seasonal variation in infection, with temperature driving this variation (Grizel \& Tigé 1982, Cáceres-Martínez et al. 1995, Culloty \& Mulcahy 1996, Engelsma et al. 2010). Seasonal peaks in prevalence have been observed particularly in the spring (Engelsma et al. 2010) or in early autumn following spawning (Culloty \& Mulcahy 1996). A study of $B$. ostreae survival with respect to temperature showed significantly higher survival at $15^{\circ} \mathrm{C}$ compared to $25^{\circ} \mathrm{C}$ (Arzul et al. 2009). This suggests that the ability of $B$. ostreae to survive may be reduced in waters where average temperatures are above $20^{\circ} \mathrm{C}$. While potential low-temperature limitation of $B$. ostreae has not been well studied, Arzul et al. (2009) confirmed survival of the parasite at $4^{\circ} \mathrm{C}$. In addition, the parasite was confirmed for the first time in a population in Norway (WAHID-Interface 2009), suggesting that low tem- peratures might not be a limiting factor in the spread of this parasite.

Like B. ostreae, B. exitiosa can be observed throughout the year, displaying only a modest seasonal cycle, as in $O$. chilensis in New Zealand where it has best been characterized (Hine 1991). Cranfield et al. (2005) described the wave of infection with $B$. exitiosa spreading through Foveaux Strait, New Zealand, followed by a wave of mortality in $O$. chilensis. B. exitiosa activity in New Zealand fits a simple epizootic model suggesting that diffusion and turbulent processes are important in transmission of the infection. While natural transmission processes of $B$. exitiosa in the southeastern USA are less well understood, the parasite does display a stronger seasonal cycle there than it does elsewhere. In C. ariakensis in North Carolina, USA, infection and resulting mortality peaked in the summer months (Carnegie et al. 2008), with the parasite much less prevalent in winter (e.g. Burreson et al. 2004). In O. stentina, which is endemic in the $B$. exitiosa-enzootic North Carolina systems, a similar temporal trend in $B$. exitiosa infection is observed, although prevalence of the parasite is typically low $(<5 \%$ ) year-round (R. B. Carnegie unpubl. data).

\section{HOST-PARASITE INTERACTIONS}

The Bonamia ostreae-Ostrea edulis system is an interesting model to investigate interactions between molluscs and their intracellular parasites. B. ostreae mainly infects haemocytes, cells with a pivotal role in the oyster defences. Phagocytosis by haemocytes is the main cellular immune response against pathogens in molluscs. However, after internalization, $B$. ostreae is able to survive and multiply in the phagocytes, escaping post-phagocytosis mechanisms. Although methods for in vitro cultivation of $B$. ostreae are lacking, a protocol for parasite isolation from infected oysters (Mialhe et al. 1988a) and short-term haemocyte cell culture methods (Mourton et al. 1992) have enabled in vitro studies on interactions between haemocytes of flat oysters and the parasite.

Contact experiments between haemocytes and parasites have facilitated a better description of the host cell responses to infection with $B$. ostreae. As soon as $30 \mathrm{~min}$ after contact, the parasite is internalized within the haemocytes. Chagot et al. (1992) showed that exposure of haemocytes or parasites to cytochalasin B, an inhibitor of microfilament function, before the contact experiment decreased parasite internalization, suggesting that not only the host cell, 
but also the parasite, contributes to its own internalization. A gene encoding B. ostreae heat shock protein 90 (HSP90) has recently been characterized, and the involvement of this protein in haemocyte invasion was investigated by pre-exposing parasites to radicicol, an HSP90-inhibitor. Haemocytes in contact with radicicol-exposed parasites appeared significantly less infected than haemocytes in contact with nontreated parasites (Prado-Alvarez et al. 2013). Flow cytometry was used to demonstrate that live parasites are phagocytosed at higher rates than fluorescent beads (Cochennec 2001). Numbers of infected haemocytes were similar after the contact with live and heatinactivated parasites; however, the mean number of parasites per infected haemocyte was higher in the first treatment (Morga et al. 2009). Moreover, examination of naturally infected flat oysters revealed that the number of tissue-infiltrating haemocytes increased with infection intensity, suggesting a recruitment process at the site of infection whereas circulating haemocyte densities were not statistically different between infected and non-infected oysters (Cochennec-Laureau et al. 2003a). The parasite might activate the recruitment of host cells before actively contributing to its own internalization.

Studies have also been carried out in order to understand recognition mechanisms between haemocytes and B. ostreae. Incubation of parasites with sugars (glucose, mannose, fucose, $\mathrm{N}$-acetyl glucosamine and galactosamine) before contact experiments induced a decrease in haemocyte infection. B. ostreae seems to possess lectin-like molecules involved in their recognition by the haemocyte (Chagot et al. 1992). A gene encoding a galectin (Oe-Gal) has been completely characterized using suppression subtractive hybridization, carried out between infected and uninfected haemocytes. This gene appeared to be over-expressed in haemocytes within $1 \mathrm{~h}$ of contact with the parasites, suggesting that the Oe-Gal is involved in the recognition of the parasite (Morga et al. 2011). Moreover, the cytoskeleton of the host cell seems to be involved in the internalization of the parasite as suggested by the over-expression of a gene coding a filamin in infected haemocytes (Morga et al. 2011) and the abundance of some genes related to the cytoskeleton in the libraries obtained from infected flat oysters (Martín-Gómez et al. 2012).

Post-internalization interactions have notably been investigated by flow cytometry: contrary to heatinactivated parasites, live $B$. ostreae induced a decrease of reactive oxygen species (ROS) production and esterase activities between 1 and $4 \mathrm{~h}$ post infection and phagocytosis activity decreased at $2 \mathrm{~h}$
(Morga et al. 2009, 2011). In addition, the expression of an extracellular superoxide dismutase (Oe-EcSOD) decreased after $1 \mathrm{~h}$ of contact. Several genes encoding proteins involved in detoxication and degradation including cytosolic SOD, omega glutathione Stransferase, tissue inhibitors of metalloproteinase and an interferon regulatory like factor were overexpressed in haemocytes in contact with live parasites (Morga et al. 2011). The energetic reserves of the host appear mobilized to obtain the energy to counter the parasite as demonstrated by the up-regulation of genes involved in metabolism, such as immunoresponsive gene 1 (Martín-Gómez et al. 2012). A significant reduction of phenoloxidase activity in the haemolymph of flat oysters infected with the parasite was also reported in comparison with uninfected oysters (da Silva et al. 2008). All of these results demonstrate that infected oysters and more particularly haemocytes develop mechanisms to degrade the parasite, but the parasite is partly able to turn off the haemocytes' metabolic destructive capacity. Mechanisms allowing intracellular survival of $B$. ostreae have mainly been investigated by measuring the impact of the parasite on haemocytes. However, few studies have directly considered parasite attributes. Hervio et al. (1991) detected acid phosphatase activity in membrane-bound organelles known as 'dense bodies' of $B$. ostreae that may be used to coat and protect the plasma membrane and in this way may contribute to the intracellular survival of the parasite. An ultracytochemical study carried out on Bonamia sp. in O. chilensis suggested that lipoid bodies might contribute to intracellular parasite survival by notably preventing lysosome-phagosome fusion through modification of the host phagosome membrane (Hine \& Wesney 1994). After internalization, the parasite seems to escape destruction and is even able to multiply after at least $2 \mathrm{~h}$ of contact. For example, some binucleate parasites were observed in haemocytes after 2 and 4 h of contact with B. ostreae (Morga et al. 2011).

The availability of oysters selected for their resistance to bonamiosis has allowed investigation of cellular and molecular mechanisms involved in the resistance of the oysters to the disease. Flow cytometry has shown that resistant oysters display higher esterase activities and higher ROS production after stimulation with phorbol myristate acetate than wild oysters (Cochennec 2001). Comparing infected and non-infected status in both groups of oysters revealed that wild infected oysters produced fewer ROS between 3 and $5 \mathrm{~d}$ after injection of the parasite while resistant infected oysters produced fewer 
ROS, especially at 8 and $30 \mathrm{~d}$ after injection (B. Morga et al. unpubl. data). The decrease in ROS production in resistant oysters might consequently lead to reduced host cellular damage compared to infected wild oysters. Concurrently, the capacity for phagocytosis appeared lower in infected resistant oysters for both cohabitation and injection infection experiments, suggesting that resistant oysters internalize fewer parasites than wild oysters and by this mechanism limit the distribution of the parasite in the different organs of the oyster (B. Morga et al. unpubl. data). Real-time quantitative reversetranscription PCR revealed an over-expression of Oe-EcSOD in vitro in haemocytes from resistant infected oysters compared to haemocytes from wild infected oysters (Morga et al. 2012). Resistant oysters might display better capacity to limit the negative impact of ROS, produced to degrade B. ostreae, on host cellular components. In contrast, this gene was down-regulated in vivo in resistant oysters challenged by injection and cohabitation. Differences observed between in vitro and in vivo conditions highlight that interactions between host and parasites are complex. While in vitro experiments help to illuminate some interactions at the cellular level, in vivo conditions reveal them at the oyster level. In addition, 3 genes involved in the modulation of apoptosis (inhibitor of apoptosis, Fas ligand and cathepsin B) were found to be over-expressed in resistant infected oysters, suggesting that induction of programmed cell death in infected haemocytes may play an important role in the resistance mechanisms (Morga et al. 2012) while the parasite might inhibit this phenomenon in order to survive in haemocytes.

In contrast to the European flat oyster O. edulis, at the cellular level the Pacific cupped oyster C. gigas is highly resistant to infection with $B$. ostreae (Renault et al. 1995). At the cellular level, C. gigas haemocytes are able to phagocytose and destroy the parasite (Chagot et al. 1992, Mourton et al. 1992). A comparison between both oyster species revealed significant differences in total and differential haemocyte counts (THC and DHC, respectively) and respiratory burst: C. gigas showed lower THC and higher numbers of granulocytes, and appeared less susceptible to interference of $B$. ostreae in the respiratory burst than $O$. edulis (Comesaña et al. 2012). Haemolymph protein profiles have also been compared by 2-dimensional electrophoresis between flat and cupped oysters and also between $O$. edulis stocks with different susceptibility to bonamiosis. The highest number of proteins was observed in C. gigas, whereas the lowest num- ber corresponded to the most susceptible $O$. edulis stock (Cao et al. 2009). Earlier work showed that enzyme activities were higher in the haemocytes of C. gigas compared to $O$. edulis, suggesting that this difference could contribute to the natural resistance of the cupped oyster to infection with $B$. ostreae (Xue \& Renault 2000).

Although many questions remain unsolved, and despite the lack of haemocyte and parasite culture systems, our understanding of interactions between oysters and the intracellular parasite $B$. ostreae and of mechanisms involved in the resistance of oysters to the disease continues to grow.

\section{DISEASE RESISTANCE AND CONTROL}

Translocation of oysters is thought to have contributed to the historical dispersal of Bonamia parasites (e.g. Elston et al. 1986), and it is still viewed as a primary cause of contemporary parasite dispersal. Given the limited options for management of the disease (see below), prevention of spread is a key component in handling the disease. The OIE International Aquatic Animal Health Code has recommended clear measures to prevent any further spread of the disease (OIE 2012). B. ostreae and B. exitiosa are classified as notifiable pathogens by the OIE and the EU, and under legislation, declaration of an occurrence of the disease is compulsory for authorities in affected countries. As a result of this, all countries within the EU are required to undertake national screening programmes to determine and monitor the disease status of their Ostrea edulis populations. Although B. exitiosa has been shown to be present at several locations in O. edulis stocks within Europe, under the current EU legislation, the parasite is still considered exotic to Europe. If an area is determined to be infected with bonamiosis, exportation of flat oysters to areas which have an equal zoosanitary status may continue, but exportation to disease-free areas is heavily limited, with any exported stock to remain in complete isolation from the native disease-free populations. Upon certification of their status, disease-free stocks can be exported without any such limitations. To prevent the further spread of the disease within a country once an infection has occurred, a zoning system is implemented around that area, with at-risk Bonamia-free areas declared protected zones, in which increased measures must be taken to prevent spread of infection. These measures may include movement control and an intensified degree of surveillance. Countries with areas with previously 
infected stocks can declare themselves $B$. ostreae free, once the aforementioned zones have been established, all infected specimens have been destroyed, a biosecurity assessment has been performed, and disease surveillance has been conducted by the relevant state authority for at least $2 \mathrm{yr}$ without any further detection of $B$. ostreae.

With the possible exception of a single isolated site with no natural population of $O$. edulis in Loch Sunart, Scotland (D. Fraser pers. comm.), eradication has not been documented from any area where $B$. ostreae has been detected. Van Banning (1987) found that even after the removal of all flat oysters from the area and a fallowing period of several years, oysters reintroduced into Lake Grevelingen, the Netherlands, developed bonamiosis. As such, prevention of the spread of bonamiosis and management of the disease in areas where it is already present are the only mechanisms available to reduce the impact of this pathogen. The near ubiquitous presence of B. ostreae in Europe today is due, in part, to past failures to implement such preventive measures (FAO 2004).

In terms of management, a selection of husbandry techniques have been introduced and modified into the farming of flat oysters in different areas to help minimise mortalities from the disease (Culloty et al. 2004). These include reducing stocking densities, fallowing beds, on-growing in deeper waters, using suspended culture, cleansing sites and fishing gear, culling oyster beds in which infection levels exceed $10 \%$ and marketing oysters after 15 to 18 mo (Grizel et al. 1988, Hugh-Jones 1994, Montes et al. 2003). The success of these strategies has been variable due to local conditions, but the reduction of stressors in the growth cycle can minimise the severity of the disease.

A similar observation has been made for $B$. exitiosa in $O$. chilensis in New Zealand: intense dredging of the oysters appeared to be a major source of stress, increasing the susceptibility of the oysters to $B$. exitiosa (Cranfield et al. 2005). With reduction of disturbances by use of lighter dredges and less damaging towing strategies, the probability of disease outbreaks may be reduced. At most locations in Europe where $B$. exitiosa has been observed, $B$. ostreae is also endemic. This makes it difficult to get a clear picture of the effect of $B$. exitiosa on $O$. edulis stocks. Hence, no specific management to reduce the impact of $B$. exitiosa is employed.

Several studies, incorporating laboratory and field trials at small and large scales, have been conducted over the past $30 \mathrm{yr}$ to investigate the ability of flat oyster stocks to develop resistance to $B$. ostreae (Elston et al. 1987, Martin et al. 1993, Boudry et al. 1996, Baud et al. 1997, Naciri-Graven et al. 1998, Culloty et al. 2001, 2004, Lapègue et al. 2003, Lynch et al. 2005). Studies have focused on breeding for resistance after either the selection of families by genetic analysis or the large-scale breeding from survivors in the field.

An early study by Elston et al. (1987) indicated that some difference in susceptibility of various stocks could be observed in the laboratory. Since then, a range of studies have been carried out throughout Europe. Several field trials have been carried out at Cork Harbour, Ireland, a B. ostreae-enzootic site since the late 1980s, to investigate the performance of the local Rossmore oyster stock (see Lynch et al. 2014, this DAO Special). These oysters have been selectively bred from survivors of disease outbreaks and mortality events on the oyster beds since the 1980s, when the parasite was first detected in this stock. When Rossmore oysters were compared to other Irish stocks that had not been selectively bred for resistance, the Rossmore oysters performed better than the 3 other Irish stocks in terms of survival and prevalence of infection, indicating that some level of resistance had been established in the Rossmore stock (Culloty et al. 2001). In a follow-up study at several European sites, Rossmore oysters and another exposed European stock from the Netherlands performed better than naïve Irish and Scottish stocks (Culloty et al. 2004). The study also indicated that very young oysters could become infected. Lynch et al. (2005) found that this difference in susceptibility could even be observed in very young oysters, i.e. spat, only several months old.

Some work on oyster breeding programmes to develop stocks resistant to $B$. ostreae has also been carried out in France, albeit with limited success (Martin et al. 1993, Boudry et al. 1996, Baud et al. 1997), as inbreeding and population bottlenecks remain an issue (Launey et al. 2001, Culloty et al. 2004). The selective breeding programme was first initiated in 1985 in France, with the production of 2 oyster populations by mass spawning (Naciri-Graven et al. 1998). Individual selection was carried out by inoculation tests and field-testing, with survivors being used as broodstock to produce 3 generations of offspring; however, the progeny exhibited low genetic diversity and were considered unsuitable for a sustainable population (Launey et al. 2001). To counteract inbreeding, oyster families were selectively bred to produce progeny with a greater genetic diversity in 1998. These families showed enhanced survival and 
a lower prevalence of infection compared to control oysters in B. ostreae-infected areas (Lapègue et al. 2003).

\section{FUTURE DIRECTIONS}

The remarkable discovery of Bonamia exitiosa in so many new hosts and locations over the last decade has already opened 2 major areas of new study. The first area involves understanding the ecology and epizootiology of this parasite in the myriad systems in which it occurs, including its interactions with $B$. ostreae where the 2 species occur together (e.g. Abollo et al. 2008). The second area involves understanding the factors influencing the dispersal of $B$. exitiosa to such locales. We may hope that genetic analyses will shed light on which component of this dispersal is natural and which is anthropogenic, either one of which may include co-dispersal with the oyster Ostrea stentina (Hill et al. 2010b). Both of these $B$. exitiosa-related research areas should receive much attention in the coming years.

A second major area of focus on bonamiosis has also begun, and will involve a biotechnological and functional focus on host-parasite interactions. Recent studies have focused on gaining a greater understanding of the response of oysters to $B$. ostreae infection (Morga et al. 2009, 2011, 2012, Comesaña et al. 2012, Martín-Gómez et al. 2012). Functional studies combining more sophisticated genetic methodology, proteomics and cellular and ultrastructural approaches will be required to better characterize how these mechanisms allow an oyster host to resist Bonamia infection and the parasite to escape host responses.

Acknowledgements. Part of the work presented in this review was facilitated by the EFSA Working Group on 'Aquatic animal species susceptible to diseases listed in Directive 2006/88/EC' and the EFSA project on the 'Epidemiology of different agents causing disease in aquatic animals'. We thank the members of the EFSA working group and project for the valuable discussions in preparation of the data included in this review, and particularly the support and contributions of Ana Afonso and Franck Berthe from EFSA. This is Virginia Institute of Marine Science publication number 3374 .

\section{LITERATURE CITED}

Abollo E, Ramilo A, Casas SM, Comesaña P, Cao A, Carballal MJ, Villalba A (2008) First detection of the protozoan parasite Bonamia exitiosa (Haplosporidia) infecting flat oyster Ostrea edulis grown in European waters.
Aquaculture 274:201-207

Arzul I, Gagnaire B, Bond C, Chollet B and others (2009) Effects of temperature and salinity on the survival of Bonamia ostreae, a parasite infecting flat oysters Ostrea edulis. Dis Aquat Org 85:67-75

Arzul I, Langlade A, Chollet B, Robert M and others (2011) Can the protozoan parasite Bonamia ostreae infect larvae of flat oysters Ostrea edulis? Vet Parasitol 179:69-76

> Audemard C, Carnegie RB, Bishop MJ, Peterson CH, Burreson EM (2008a) Interacting effects of temperature and salinity on Bonamia sp. parasitism in the Asian oyster Crassostrea ariakensis. J Invertebr Pathol 98:344-350

Audemard C, Carnegie RB, Stokes NA, Bishop MJ, Peterson $\mathrm{CH}$, Burreson EM (2008b) Effects of salinity on Bonamia sp. survival in the Asian oyster Crassostrea ariakensis. J Shellfish Res 27:535-540

Balouet G, Poder M, Cahour A (1983) Haemocytic parasitosis: morphology and pathology of lesions in the French flat oyster, Ostrea edulis L. Aquaculture 34:1-14

Balseiro P, Conchas RF, Montes J, Gómez León J, Novoa B, Figueras A (2006) Comparison of diagnosis techniques for the protozoan parasite Bonamia ostreae in flat oyster Ostrea edulis. Aquaculture 261:1135-1143

Baud JP, Gérard A, Naciri-Graven Y (1997) Comparative growth and mortality of Bonamia ostreae-resistant and wild flat oysters, Ostrea edulis, in an intensive system. I. First year of experiment. Mar Biol 130:71-79

> Berthe FCJ, Hine PM (2003) Bonamia exitiosa Hine et al. 2001 is proposed instead of $B$. exitiosus as the valid name of Bonamia sp. infecting flat oysters Ostrea chilensis in New Zealand. Dis Aquat Org 57:181

Bishop MJ, Carnegie RB, Stokes NA, Peterson CH, Burreson EM (2006) Complications of a non-native oyster introduction: facilitation of a local parasite. Mar Ecol Prog Ser 325:145-152

Boudry P, Chatain B, Naciri-Graven Y, Lemaire C, Gerard (1996) Genetical improvement of marine fish and shellfish: a French perspective. Proc FOID ‘96 5:141-150

Bougrier S, Tigé G, Bachère E, Grizel H (1986) Ostrea angasi acclimatization to French coasts. Aquaculture 58:151-154

Boulo V, Mialhe E, Rogier H, Paolucci F, Grizel H (1989) Immunodiagnosis of Bonamia ostreae (Ascetospora) infection of Ostrea edulis L. and subcellular identification of epitopes by monoclonal antibodies. J Fish Dis 12: 257-262

Bucke D, Hepper B (1987) Bonamia ostreae infecting Ostrea lutaria in the U.K. Bull Eur Assoc Fish Pathol 7:79-80

- Burreson EM, Stokes NA, Carnegie RB, Bishop MJ (2004) Bonamia sp. (Haplosporidia) found in nonnative oysters Crassostrea ariakensis in Bogue Sound, North Carolina. J Aquat Anim Health 16:1-9

Cáceres-Martínez J, Robledo JAF, Figueras A (1995) Presence of Bonamia and its relation to age, growth rates and gonadal development of the flat oyster, Ostrea edulis, in the Ría de Vigo, Galicia (NW Spain). Aquaculture 130: $15-23$

Campalans M, Rojas P, Gonzalez M (2000) Haemocytic parasitosis in the farmed oyster Tiostrea chilensis. Bull Eur Assoc Fish Pathol 20:31-33

> Cao A, Fuentes J, Comesaña P, Casas SM, Villalba A (2009) A proteomic approach envisaged to analyse the bases of oyster tolerance/resistance to bonamiosis. Aquaculture 295:149-156

Carnegie RB, Burreson EM (2011) Declining impact of an introduced pathogen: Haplosporidium nelsoni in the 
oyster Crassostrea virginica in Chesapeake Bay. Mar Ecol Prog Ser 432:1-15

> Carnegie RB, Cochennec-Laureau N (2004) Microcell parasites of oysters: recent insights and future trends. Aquat Living Resour 17:519-528

Carnegie RB, Barber BJ, Culloty SC, Figueras AJ, Distel DL (2000) Development of a PCR assay for detection of the oyster pathogen Bonamia ostreae and support for its inclusion in the Haplosporidia. Dis Aquat Org 42:199-206

$>$ Carnegie RB, Barber BJ, Distel DL (2003) Detection of the oyster parasite Bonamia ostreae by fluorescent in situ hybridization. Dis Aquat Org 55:247-252

> Carnegie RB, Burreson EM, Hine PM, Stokes NA, Audemard C, Bishop MJ, Peterson CH (2006) Bonamia perspora n. sp. (Haplosporidia), a parasite of the oyster Ostreola equestris, is the first Bonamia species known to produce spores. J Eukaryot Microbiol 53:232-245

> Carnegie RB, Stokes NA, Audemard C, Bishop MJ and others (2008) Strong seasonality of Bonamia sp. infection and induced Crassostrea ariakensis mortality in Bogue and Masonboro Sounds, North Carolina, USA. J Invertebr Pathol 98:335-343

> Carnegie RB, Hill KM, Stokes NA, Burreson EM (2014) The haplosporidian Bonamia exitiosa is present in Australia, but the identity of the parasite described as Bonamia (formerly Mikrocytos) roughleyi is uncertain. J Invertebr Pathol 115:33-40

> Carrasco N, Villalba A, Andree KB, Engelsma MY and others (2012) Bonamia exitiosa (Haplosporidia) observed infecting the European flat oyster Ostrea edulis cultured on the Spanish Mediterranean coast. J Invertebr Pathol 110:307-313

> Chagot D, Boulo V, Hervio D, Mialhe E, Bachère E, Mourton C, Grizel H (1992) Interactions between Bonamia ostreae (Protozoa: Ascetospora) and hemocytes of Ostrea edulis and Crassostrea gigas (Mollusca: Bivalvia): entry mechanisms. J Invertebr Pathol 59:241-249

Cochennec N (2001) Bonamia ostreae, parasite de l'huitre plate, Ostrea edulis: sa position taxonomique parmi les parasites du groupe 'microcell', analyses des interactions hôte/parasite chez plusieurs populations d'huître plates. $\mathrm{PhD}$ thesis, Université La Rochelle

> Cochennec N, Hervio D, Panatier B, Boulo V and others (1992) A direct monoclonal antibody sandwich immunoassay for detection of Bonamia ostreae (Ascetospora) in hemolymph samples of the flat oyster Ostrea edulis (Mollusca: Bivalvia). Dis Aquat Org 12:129-134

> Cochennec N, Renault T, Boudry P, Chollet B, Gérard A (1998) Bonamia-like parasite found in the Suminoe oyster Crassostrea rivularis reared in France. Dis Aquat Org 34:193-197

> Cochennec N, Le Roux F, Berthe F, Gérard A (2000) Detection of Bonamia ostreae based on small subunit ribosomal probe. J Invertebr Pathol 76:26-32

> Cochennec-Laureau N, Auffret M, Renault BT, Langlade A (2003a) Changes in circulating and tissue-infiltrating hemocyte parameters of European flat oysters, Ostrea edulis, naturally infected with Bonamia ostreae. J Invertebr Pathol 83:23-30

- Cochennec-Laureau N, Reece KS, Berthe FCJ, Hine PM (2003b) Mikrocytos roughleyi taxonomic affiliation leads to the genus Bonamia (Haplosporidia). Dis Aquat Org 54: 209-217

Comesaña P, Casas SM, Cao A, Abollo E, Arzul I, Morga B, Villalba A (2012) Comparison of haemocytic parameters among flat oyster Ostrea edulis stocks with different susceptibility to bonamiosis and the Pacific oyster Crassostrea gigas. J Invertebr Pathol 109:274-286

Corbeil S, Arzul I, Diggles B, Heasman M, Chollet B, Berthe FCJ, Crane MS (2006a) Development of a TaqMan PCR assay for the detection of Bonamia species. Dis Aquat Org 71:75-80

Corbeil S, Arzul I, Robert M, Berthe FCJ, Besnard-Cochennec N, Crane MS (2006b) Molecular characterisation of an Australian isolate of Bonamia exitiosa. Dis Aquat Org 71: 81-85

Cranfield HJ, Dunn A, Doonan IJ, Michael KP (2005) Bonamia exitiosa epizootic in Ostrea chilensis from Foveaux Strait, southern New Zealand between 1986 and 1992. ICES J Mar Sci 62:3-13

Culloty SC, Mulcahy MF (1996) Season-, age-, and sexrelated variation in the prevalence of bonamiasis in flat oysters (Ostrea edulis L.) on the south coast of Ireland. Aquaculture 144:53-63

Culloty SC, Mulcahy MF (2007) Bonamia ostreae in the native oyster Ostrea edulis: a review. Mar Environ Health Ser 29:1-36

Culloty SC, Cronin MA, Mulcahy MF (2001) An investigation into the relative resistance of Irish flat oysters Ostrea edulis L. to the parasite Bonamia ostreae (Pichot et al. 1980). Aquaculture 199:229-244

> Culloty SC, Cronin MA, Mulcahy MF (2004) Potential resistance of a number of populations of the oyster Ostrea edulis to the parasite Bonamia ostreae. Aquaculture 237: 41-58

da Silva PM, Villalba A (2004) Comparison of light microscopic techniques for the diagnosis of the infection of the European flat oyster Ostrea edulis by the protozoan Bonamia ostreae. J Invertebr Pathol 85:97-104

da Silva PM, Comesaña P, Fuentes J, Villalba A (2008) Variability of haemocyte and haemolymph parameters in European flat oyster Ostrea edulis families obtained from brood stocks of different geographical origins and relation with infection by the protozoan Bonamia ostreae. Fish Shellfish Immunol 24:551-563

> Diggles BK, Cochennec-Laureau N, Hine PM (2003) Comparison of diagnostic techniques for Bonamia exitiosus from flat oysters Ostrea chilensis in New Zealand. Aquaculture 220:145-156

> Dinamani P, Hine PM, Jones JB (1987) Occurrence and characteristics of the haemocyte parasite Bonamia sp. in the New Zealand dredge oyster Tiostrea lutaria. Dis Aquat Org 3:37-44

Doonan IJ, Cranfield HJ, Michael KP (1994) Catastrophic reduction of the oyster, Tiostrea chilensis (Bivalvia: Ostreidae), in Foveaux Strait, New Zealand, due to infestation by the protistan Bonamia sp. N Z J Mar Freshw Res 28:335-344

Dungan CF, Carnegie RB, Hill KM, McCollough CB and others (2012) Diseases of oysters Crassostrea ariakensis and $C$. virginica reared in ambient waters from the Choptank River, Maryland and the Indian River Lagoon, Florida. Dis Aquat Org 101:173-183

EFSA (European Food Safety Authority) (2008) Scientific opinion of the Panel on AHAW on a request from the European Commission on aquatic animal species susceptible to diseases listed in Directive 2006/88/EC. EFSA J 808:1-144

Elston RA, Farley CA, Kent ML (1986) Occurrence and significance of bonamiasis in European flat oysters Ostrea 
edulis in North America. Dis Aquat Org 2:49-54

Elston RA, Kent ML, Wilkinson MT (1987) Resistance of Ostrea edulis to Bonamia ostreae infection. Aquaculture 64:237-242

Engelsma MY, Kerkhoff S, Roozenburg I, Haenen OLM and others (2010) Epidemiology of Bonamia ostreae infecting European flat oysters Ostrea edulis from Lake Grevelingen, The Netherlands. Mar Ecol Prog Ser 409:131-142

FAO (Food and Agriculture Organization of the United Nations) (2004) Cultured aquatic species information programme, Ostrea edulis. FAO, Rome, available at www.fao.org/fishery/culturedspecies/Ostrea_edulis/en (accessed 10 July 2013)

Farley CA, Wolff PH, Elston RA (1988) A longterm study of 'microcell' disease in oysters with a description of a new genus, Mikrocytos (g.n.), and two new species, Mikrocytos mackini (sp.n.) and Mikrocytos roughleyi (sp.n.). Fish Bull 86:581-593

Flannery G, Lynch SA, Longshaw M, Stone D and others (2014) Interlaboratory variability in screening for Bonamia ostreae, a protistan parasite of the European flat oyster Ostrea edulis. Dis Aquat Org 110:93-99

Grizel H (1985) Etude des recentes epizooties de l'huitre plate Ostrea edulis Linne et de leur impact sur l'ostreiculture bretonne. PhD thesis, Universite des sciences et techniques du Languedoc, Montpellier

Grizel H, Tigé G (1982) Evolution of the haemocytic disease caused by Bonamia ostreae. In: Burges HD, Payne CC (eds) Invertebrate pathology and microbial control. Proceedings of the XVth Annual Meeting of the Society for Invertebrate Pathology, 1 Sep 1982, Brighton. University of Sussex, Brighton, p 258-260

Grizel H, Comps M, Raguenes D, Leborgne Y, Tigé G, Martin AG (1983) Bilan des essais d'acclimatation d'Ostrea chilensis sur les cotes de Bretagne. Rev Trav Inst Pêch Marit 46:209-225

Grizel H, Mialhe E, Chagot D, Boulo V, Bachère E (1988) Bonamiasis: a model study of diseases in marine molluscs. In: Fisher WS (ed) Disease processes in marine bivalve molluscs. Spec Publ 18. American Fisheries Society, Bethesda, MD, p 1-4

Heasman M, Diggles BK, Hurwood D, Mather P, Pirozzi I, Dworjanyn S (2004) Paving the way for continued rapid development of the flat (angasi) oyster (Ostrea angasi) farming industry in New South Wales. NSW Fisheries Final Report Series No 66. NSW Fisheries, Nelson Bay

Hervio D, Chagot D, Godin P, Grizel H, Mialhe E (1991) Localization and characterization of acid phosphatase activity in Bonamia ostreae (Ascetospora), an intrahemocytic protozoan parasite of the flat oyster Ostrea edulis (Bivalvia). Dis Aquat Org 12:67-70

Hill B, Reese A, Dixon P, Oidtmann B and others (2010a) Epidemiology of different agents causing disease in aquatic animals. EFSA Scientific Report. EFSA, Parma

> Hill KM, Carnegie RB, Aloui-Bejaoui N, El Gharsalli R, White DM, Stokes NA, Burreson EM (2010b) Observation of a Bonamia sp. infecting the oyster Ostrea stentina in Tunisia, and a consideration of its phylogenetic affinities. J Invertebr Pathol 103:179-185

Hill KM, Stokes NA, Webb SC, Hine PM and others (2014) Phylogenetics of Bonamia parasites based on small subunit and internal transcribed spacer region ribosomal DNA sequence data. Dis Aquat Org 110:33-54

> Hine PM (1991) The annual pattern of infection by Bonamia sp. in New Zealand flat oysters, Tiostrea chilensis. Aqua- culture 93:241-251

- Hine PM, Jones JB (1994) Bonamia and other aquatic parasites of importance to New Zealand. NZ J Zool 21:49-56

$>$ Hine PM, Wesney B (1994) The functional cytology of Bonamia sp. (Haplosporidia) infecting oysters Tiostrea chilensis: an ultracytochemical study. Dis Aquat Org 20: 207-217

> Hine PM, Cochennec-Laureau N, Berthe FCJ (2001) Bonamia exitiosus n. sp. (Haplosporidia) infecting flat oysters Ostrea chilensis in New Zealand. Dis Aquat Org 47:63-72

Howard AE (1994) The possibility of long distance transmission of Bonamia by fouling on boat hulls. Bull Eur Assoc Fish Pathol 14:211-212

Hudson EB, Hill BJ (1991) Impact and spread of bonamiasis in the UK. Aquaculture 93:279-285

Hugh-Jones D (1994) Farming the European flat oyster in Ireland today. Bull Aquacult Assoc Can 94:3-8

Katkansky SC, Dahlstrom WA, Warner RW (1969) Observations on survival and growth of the European flat oyster, Ostrea edulis, in California. Calif Fish Game 55:69-74

Kroeck MA (2010) Gross signs and histopathology of Ostrea puelchana infected by a Bonamia exitiosa-like parasite (Haplosporidia). Dis Aquat Org 89:229-236

Kroeck MA, Montes J (2005) Occurrence of the haemocyte parasite Bonamia sp. in flat oysters Ostrea puelchana farmed in San Antonio Bay (Argentina). Dis Aquat Org 63:231-235

Lapègue $\mathrm{S}$, Bédier E, Goyard E, Dégremont L and others (2003) Apport d'un programme de génétique à une filière de production aquacole: l'exemple de 'ostréiculture. Actes de Colloque Styli 2003 Ifremer. http://archimer. ifremer.fr/doc/2003/acte-3491.pdf

> Launey S, Barre M, Gerard A, Naciri-Graven Y (2001) Population bottleneck and effective size in Bonamia ostreaeresistant populations of Ostrea edulis as inferred by microsatellite markers. Genet Res 78:259-270

Lohrmann KB, Hine PM, Campalans M (2009) Ultrastructure of Bonamia sp. in Ostrea chilensis in Chile. Dis Aquat Org 85:199-208

> López-Flores I, Suárez-Santiago VN, Longet D, Saulnier D, Chollet B, Arzul I (2007) Characterization of actin genes in Bonamia ostreae and their application to phylogeny of the Haplosporidia. Parasitology 134:1941-1948

Lynch SA, Armitage DV, Wylde S, Mulcahy MF, Culloty SC (2005) The susceptibility of young prespawning oysters, Ostrea edulis, to Bonamia ostreae. J Shellfish Res 24: 1019-1025

> Lynch SA, Armitage DV, Coughlan J, Mulcahy MF, Culloty SC (2007) Investigating the possible role of benthic macroinvertebrates and zooplankton in the life cycle of the haplosporidian Bonamia ostreae. Exp Parasitol 115: 359-368

Lynch SA, Mulcahy MF, Culloty S (2008) Efficiency of diagnostic techniques for the parasite, Bonamia ostreae, in the flat oyster, Ostrea edulis. Aquaculture 281:17-21

> Lynch SA, Abollo E, Ramilo A, Cao A, Culloty SC, Villalba A (2010) Observations raise the question if the Pacific oyster, Crassostrea gigas, can act as either a carrier or a reservoir for Bonamia ostreae or Bonamia exitiosa. Parasitology 137:1515-1526

> Lynch SA, Flannery G, Hugh-Jones T, Hugh-Jones D, Culloty SC (2014) Thirty-year history of Irish (Rossmore) Ostrea edulis selectively bred for disease resistance to Bonamia ostreae. Dis Aquat Org 110:113-121

Martin AG, Gérard A, Cochennec N, Langlade A (eds) 
(1993) Selecting flat oysters, Ostrea edulis, for survival against the parasite Bonamia ostreae: assessment of resistance of a first selected generation. In: Barnabé G, Kestemont P (eds) Production, environment and quality. Bordeaux Aquaculture '92. Spec Publ No. 18. European Aquaculture Society, Ghent, p 545-554

Martín-Gómez L, Villalba A, Abollo E (2012) Identification and expression of immune genes in the flat oyster Ostrea edulis in response to bonamiosis. Gene 492:81-93

> Marty G, Bower SM, Clarke K, Meyer G and others (2006) Histopathology and a real-time PCR assay for detection of Bonamia ostreae in Ostrea edulis cultured in western Canada. Aquaculture 261:33-42

> McArdle JF, McKiernan F, Foley H, Jones DH (1991) The current status of Bonamia disease in Ireland. Aquaculture 93:273-278

Mialhe E, Bachère E, Chagot D, Grizel H (1988a) Isolation and purification of the protozoan Bonamia ostreae (Pichot et al. 1980), a parasite affecting the flat oyster Ostrea edulis L. Aquaculture 71:293-299

Mialhe E, Boulo V, Elston RA, Hill BJ and others (1988b) Seriological analysis of Bonamia in Ostrea edulis and Tiostrea lutaria using polyclonal and monoclonal antibodies. Aquat Living Resour 1:67-69

Montes J (1990) Development of Bonamia ostreae parasitosis of flat oyster (Ostrea edulis) from Galicia, Northwest Spain. In: Perkins FO, Cheng TC (eds) Pathology in marine science. Academic Press, London, p 223-227

Montes J, Ferro-Soto B, Conchas RF, Guerra A (2003) Determining culture strategies in populations of the European flat oyster, Ostrea edulis, affected by bonamiosis. Aquaculture 220:175-182

> Morga B, Arzul I, Chollet B, Renault T (2009) Infection with the protozoan parasite Bonamia ostreae modifies in vitro haemocyte activities of flat oyster Ostrea edulis. Fish Shellfish Immunol 26:836-842

Morga B, Arzul I, Faury N, Segarra A, Chollet B, Renault T (2011) Molecular responses of Ostrea edulis haemocytes to an in vitro infection with Bonamia ostreae. Dev Comp Immunol 35:323-333

> Morga B, Renault T, Faury N, Arzul I (2012) New insights in flat oyster Ostrea edulis resistance against the parasite Bonamia ostreae. Fish Shellfish Immunol 32:958-968

Mourton C, Boulo V, Chagot D, Hervio D, Bachère E, Mialhe E, Grizel H (1992) Interactions between Bonamia ostreae (Protozoa: Ascetospora) and hemocytes of Ostrea edulis and Crassostrea gigas (Mollusca: Bivalvia): in vitro system establishment. J Invertebr Pathol 59:235-240

Naciri-Graven Y, Martin AG, Baud JP, Renault T, Gérard A (1998) Selecting the flat oyster Ostrea edulis (L.) for survival when infected with the parasite Bonamia ostreae. J Exp Mar Biol Ecol 224:91-107

> Narcisi V, Arzul I, Cargini D, Mosca F and others (2010) Detection of Bonamia ostreae and B. exitiosa (Haplosporidia) in Ostrea edulis from the Adriatic Sea (Italy). Dis Aquat Org 89:79-85

OIE (World Organisation for Animal Health) (2012) Manual of diagnostic tests for aquatic animals. World Organisation for Animal Health, Paris

Pascual M, Martin AG, Zampatti E, Coatanea D, Defossez J, Robert R (1991) Testing of the Argentina oyster, Ostrea puelchana, in several French oyster farming sites. ICES CM 1991/K:30. International Council for the Exploration of the Sea, Copenhagen

Peeler EJ, Oidtmann BC, Midtlyng PJ, Miossec L, Gozlan RE
(2010) Non-native aquatic animals introductions have driven disease emergence in Europe. Biol Invasions 13: 1291-1303

Pichot Y, Comps M, Tigé G, Grizel H, Rabouin MA (1980) Recherches sur Bonamia ostreae gen. n., sp. n., parasite nouveau de l'huitre plate Ostrea edulis L. Rev Trav Inst Pêch Marit 43:131-140

Polson MP, Hewson WE, Eernisse DJ, Baker PK, Zacherl DC (2009) You say conchaphila, I say lurida: molecular evidence for restricting the Olympia oyster (Ostrea lurida Carpenter 1864) to temperate western North America. J Shellfish Res 28:11-21

> Prado-Alvarez M, Chollet B, Couraleau Y, Morga B, Arzul I (2013) Heat shock protein 90 of Bonamia ostreae: characterization and possible correlation with infection of the flat oyster, Ostrea edulis. J Eukaryot Microbiol 60: 257-266

Ramilo A, Navas JI, Villalba A, Abollo E (2013) Speciesspecific diagnostic assays for Bonamia ostreae and B. exitiosa in European flat oyster Ostrea edulis: conventional, real-time and multiplex PCR. Dis Aquat Org 104:149-161

> Reece KS, Siddall ME, Stokes NA, Burreson EM (2004) Molecular phylogeny of the Haplosporidia based on two independent gene sequences. J Parasitol 90:1111-1122

Renault BT, Cochennec N, Grizel H (1995) Bonamia ostreae, parasite of the European flat oyster, Ostrea edulis, does not experimentally infect the Japanese oyster, Crassostrea gigas. Bull Eur Assoc Fish Pathol 15:78-80

Robert M, Garcia C, Chollet B, Lopez-Flores I and others (2009) Molecular detection and quantification of the protozoan Bonamia ostreae in the flat oyster, Ostrea edulis. Mol Cell Probes 23:264-271

Shilts MH, Pascual MS, Ó Foighil D (2007) Systematic, taxonomic and biogeographic relationships of Argentine fat oysters. Mol Phylogenet Evol 44:467-473

Spiers ZB, Gabor M, Fell SA, Carnegie RB and others (2014) Longitudinal study of winter mortality disease in Sydney rock oysters Saccostrea glomerata. Dis Aquat Org 110: 151-164

> Stentiford GD, Bonami JR, Alday-Sanz V (2009) A critical review of susceptibility of crustaceans to Taura syndrome, Yellowhead disease and White Spot Disease and implications of inclusion of these diseases in European legislation. Aquaculture 291:1-17

- Van Banning P (1987) Further results of the Bonamia ostreae challenge tests in Dutch oyster culture. Aquaculture 67: 191-194

> Van Banning P (1991) Observations on bonamiasis in the stock of the European flat oyster, Ostrea edulis, in the Netherlands, with special reference to the recent developments in Lake Grevelingen. Aquaculture 93:205-211

WAHID-Interface (World Animal Health Information Database-Interface) (2009) Infection with Bonamia ostreae, Norway 05/06/2009. OIE World Animal Health Information Database, OIE, Paris. Available at www.oie.int/ wahis_2/public/wahid.php/Reviewreport/Review?page_ refer=MapFullEventReport\&reportid=8166

WAHID-Interface (2010) Infection with Bonamia exitiosa, Italy 25/08/2010. OIE World Animal Health Information Database, OIE, Paris. Available at www.oie.int/wahis_2/ public/wahid.php/Reviewreport/Review?page_refer=Map FullEventReport\&reportid=9619

WAHID-Interface (2011) Infection with Bonamia exitiosa, UK 22/02/2011. OIE World Animal Health Information Database, OIE, Paris. Available at www.oie.int/wahis_2/ 
public/wahid.php/Reviewreport/Review?page_refer=Map FullEventReport\&reportid=10283

WAHID-Interface (2012) Infection with Bonamia exitiosa, USA 28/08/2012. OIE World Animal Health Information Database, OIE, Paris. Available at www.oie.int/wahis_2/ public/wahid.php/Reviewreport/Review?page_refer=Map FullEventReport\&reportid=12246

WAHID-Interface (2013) Infection with Bonamia exitiosa, USA 27/06/2013. OIE World Animal Health Information

Editorial responsibility: Stephen Feist, Weymouth, UK
Database, OIE, Paris. Available at www.oie.int/wahis_2/ public/wahid.php/Reviewreport/Review?page_refer=Map FullEventReport\&reportid $=14070$

Xue Q, Renault T (2000) Enzymatic activities in European flat oyster, Ostrea edulis, and Pacific oyster, Crassostrea gigas, hemolymph. J Invertebr Pathol 76:155-163

Zabaleta A, Barber BJ (1996) Prevalence, intensity, and detection of Bonamia ostreae in Ostrea edulis in the Damariscotta River, Maine. J Shellfish Res 15:395-400

Submitted: October 21, 2013; Accepted: March 6, 2014

Proofs received from author(s): June 23, 2014 